\title{
The influence of organisational rewards on workplace trust and work engagement
}

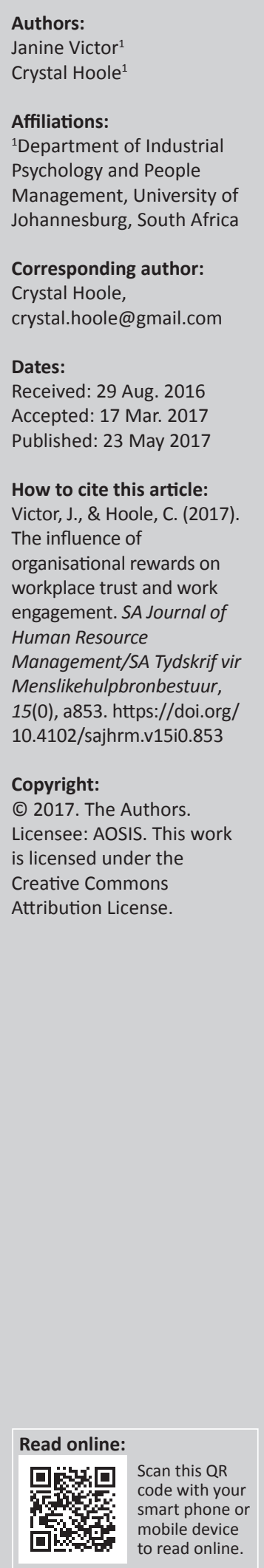

Orientation: In volatile and competitive business environments, organisations are faced with challenges to retain talented workers. Employees are increasingly leaving their jobs for a number of reasons, one of them being a perceived lack of adequate reward practices. Consequently, this has impacted on employee work engagement and confidence and trust in organisations.

Research purpose: The study sought to determine whether there is a relationship between rewards, trust and engagement, as well as whether rewards are able to predict trust and engagement in the South African workplace.

Motivation for the study: Organisations can no longer solely rely on extrinsic rewards to retain talent. Companies must draw on both extrinsic and intrinsic reward strategies to improve retention levels through endorsing higher levels of workplace trust and work engagement levels.

Research design, approach and method: A quantitative, exploratory and cross-sectional research design was utilised. Non-probability sampling using questionnaires consisting of scales from the Job Satisfaction Survey, Intrinsic Motivation Inventory, Psychological Meaningfulness Scale, Basic Needs at Work Scale, Workplace Trust Survey and Utrecht Work Engagement Scale were administered to a sample $(N=251)$ of South African employees in various industries within the Gauteng region.

Main findings: Results indicated that there is a moderate-to-strong positive relationship between the three constructs, and that rewards are able to predict trust and engagement.

Practical and managerial implications: The findings provide insight for behavioural practitioners to potentially draw upon when improving talent management strategies. Both extrinsic and intrinsic rewards are important factors in keeping employees engaged and ultimately retaining them.

Contribution: The study provided insight into the influence that organisational rewards may have on workplace trust, work engagement and retaining employees. Findings contribute towards improving talent management strategies.

\section{Introduction}

The world of work has transformed drastically over the past two decades. With perpetual shifts in volatile environments, global firms are expecting their workforce to become equipped with more flexibility, new skill sets and the ability to adapt to the increasing pressures and demands that this emerging century presents (International Labour Office, 2006). What is more, organisations are competing with one another to attract and retain global talent (Kuptsch \& Pang, 2006; Scott, McMulllen \& Royal, 2012).

In the current economic climate, organisations are often forced to make changes to their reward and talent structures. This emanates as a result of organisations experiencing high turnover rates as skilled workers are increasingly leaving their current positions due to a perceived lack of adequate reward practices. This includes, for example, poor promotional opportunities, unsuitable pay structures, supervisory issues and challenges surrounding other benefits and incentives (Jiang, Xiao, Qi \& Xiao, 2009; Nyaga, 2015; Robyn \& Du Preez, 2013; Scott et al., 2012).

In an attempt to sustain organisational survival, downsizing and cost-saving practices through the use of reducing cost to company reward strategies have not only adversely impacted on employees' levels of work engagement (Scott et al., 2012) but have also reduced their confidence and trust in organisations as well (Fehr \& List, 2004; Reinardy, 2010). 
Exploring talent management concepts such as organisational rewards, workplace trust and work engagement has thus become crucial for the survival of organisations during competitive times (Balakrishnan, Masthan \& Chandra, 2013; Enguene, 2015; Hytter, 2007; Kompaso \& Sridevi, 2010; Kwenin, Muathe \& Nzulwa, 2013; WorldatWork, 2006).

\section{Literature review \\ Organisational rewards}

Organisational rewards are deemed important aspects within the workplace (Aslam, Ghaffar, Talha \& Mushtaq, 2015; Bussin \& Van Rooy, 2014). Rewards have been defined as the financial, non-financial and psychological benefits that an organisation provides to workers in return for their contributions and efforts (Bratton \& Gold, 2003; Haider, Aamir, Hamid \& Hashim, 2015). Over the years, there has been a gradual shift in the nature of rewards towards encompassing more than just basic pay. As such, rewards may be intrinsic (internal to an individual), extrinsic (external to an individual), monetary (financial), non-monetary (nonfinancial) and direct (compensation for work conducted) or indirect (additional benefits) and may be used for a multitude of reasons and purposes. For example, rewards are often used to enhance motivation or performance (Aktar, Sachu \& Ali, 2012; Hamukwaya \& Yazdanifard, 2014), attract and retain human capital (Bussin \& Toerien, 2015; WorldatWork, 2006), increase work engagement (Ram \& Prabhaker, 2011) and heighten job satisfaction (Oriarewo, Agbim \& Owutuamor, 2013; Ram \& Prabhaker, 2011), amongst others.

\section{Extrinsic rewards}

As a legal obligation and inherent to a job, extrinsic rewards are those salient incentives useful for attracting and retaining members of the workforce (Armstrong \& Stephens, 2005; Nujjoo \& Meyer, 2012). From a traditional perspective, Porter and Lawler (1968) defined rewards as the tangible benefits that employees receive for conducting their work. From a growing contemporary point of view, extrinsic rewards are increasingly being recognised and distinguished as either monetary or non-monetary in nature (Kimutai \& Sakataka, 2015; Kshirsagar \& Waghale, 2014).

Weatherly (2002) and Osa (2014) articulated that monetary rewards are those rewards which are tangible such as financial and money-driven incentives used to reward employee performance. Examples of these types of rewards include pay, promotion (which incorporates an increase in pay) and bonuses. Non-monetary rewards, on the other hand, are intangible and non-financial incentives such as fringe benefits and contingent rewards which comprise praise and personal recognition (Sajuyigbe, Olaoye \& Adeyemi, 2013; Weatherly, 2002). According to Malhorta, Budhwar and Prowse (2007) and Mottaz (1985) as cited in Nujjoo and Meyer (2012), other types of extrinsic nonmonetary rewards include social rewards which constitute the interpersonal relationships between the employee and his or her supervisors and co-workers.
Ample evidence exists which supports that extrinsic rewards have an influence on employee motivation (Aktar et al., 2012; Arnolds \& Venter, 2007; Bowen, 2000; Hafiza, Shah, Jamsheed \& Zaman, 2011). From an organisational perspective, work motivation is concerned with those aspects and forces that drive certain behaviours such as performing well (Omollo \& Oloko, 2015; Takawira, Coetzee \& Schreuder, 2014).

In past studies, it has been emphasised that extrinsic rewards are not motivators (Bowen, 2000; Oriarewo et al., 2013). Instead, they serve as those aspects which can either satisfy or dissatisfy a person. Wilson and Eckel (2003) argued that employees will only do the necessary to obtain an extrinsic reward (such as minimally doing what is required to obtain pay) which results in short-term compliance and which may ultimately lead to resentment. This is further confirmed by Wei and Yazdanifard (2014) who argued that monetary and financial rewards lead to satisfaction over the short term.

The need to explore extrinsic rewards in the workplace over the past decade has been highlighted by numerous authors. Van Aswegen et al. (2009) argued that leaders who place their sole focus on motivating employees by means of extrinsic rewards often come across difficulties in sustaining a motivated workforce. Armstrong and Stephens (2005) articulated that extrinsic rewards, and more specifically pay, may help an organisation attract and retain employees. In terms of short-term benefits, these authors both argued that tangible extrinsic rewards may help heighten levels of employee effort and reduce dissatisfaction.

\section{Intrinsic rewards}

Intrinsic rewards are commonly defined as the rewards which are generally obtained from an employee's involvement in tasks and activities (Byars \& Rue, 2011). Intrinsic rewards constitute rewards which are associated with personal and inner fulfilment that employees' experience when they achieve something (Van Aswegen et al., 2009). They are intangible and self-generated in that they are psychological, positive, meaningful and encompass an emotional, work-related experience which individuals obtain from their work (Stumpf, Tymon, Favorito \& Smith, 2013; Thomas, 2009).

Intrinsic rewards are classified in different ways (Jacobs, Renard \& Snelgar, 2014) and have been found to drive employee motivation which includes meaningful work (Stumpf et al., 2013), autonomy, recognition, appreciation and challenging tasks, amongst others (Hafiza et al., 2011; Ozütku, 2012).

According to Thomas (2009), the changing motivational dynamics in the workplace have increased the need for intrinsic rewards. He proposed that employees in contemporary organisations need to be more self-managed. In this context, self-management means that employees direct their own work activities which includes a sense 
of meaningfulness, choice, competence and progress (Jacobs et al., 2014; Thomas, 2009). For the purpose of this study, the focus of intrinsic rewards is based on any experience which provides an employee with work that is meaningful and reaps interest and enjoyment. Furthermore, intrinsic rewards include an employees' perception of whether they have a sense of autonomy in their jobs (Ryan \& Deci, 2000).

The first dimension to be included in this study is meaningfulness, which is derived from Thomas's (2009) model of intrinsic rewards. A sense of meaningfulness refers to the roles, tasks and duties that employees perform, which forms part of a higher purpose and portrays job worth (Jacobs et al., 2014; Thomas, 2009). The second dimension included in this study is job interest and enjoyment, as derived from the self-determination theory. This theory is concerned with human motivation and personality and holds that when people perceive themselves as competent and, experience a sense of belonging and autonomy, they engage in selfdetermination. This allows them to become intrinsically motivated towards pursuing their interests (Ryan \& Deci, 2000). Harackiewicz and Hulleman (2010), therefore, defined interest as comprising of having consideration for something, regarding it as important, and having positive feelings towards it. On the other hand, enjoyment is defined by Tamborini, Bowman, Eden, Grizzard and Organ (2010) as the response of experiencing pleasure towards something.

The final dimension deemed significant in the exploration of intrinsic rewards is a sense of autonomy. Autonomy can be conceptualised as the amount of choice and psychological freedom that an employee has when carrying out his or her job (Van den Broeck, Vansteenkiste, De Witte, Soenens \& Lens, 2010). Autonomy has further been defined as the degree to which employees are able to make decisions and feel trusted in carrying out their work efforts and performances (Zigarmi, Houson, Witt \& Diehl, 2011).

Owing to the changing nature of the workplace, there is an increasing need to study and explore the role that intrinsic rewards play within the workplace (Thomas, 2009). It has been discovered that intrinsic rewards have a significant influence on job satisfaction (Rafiq, Javed, Khan \& Ahmed, 2012), motivation (Ram \& Prabhaker, 2011), work engagement (Jacobs et al., 2014) and work performance (Aktar et al., 2012).

\section{Total rewards}

As opposed to rewarding employees solely through pay and monetary benefits, the concept of total rewards provides a holistic approach to viewing rewards that employees receive from engaging in the employment relationship (Nazir, Shah \& Zaman, 2012). Total reward strategies encapsulate the sum total of those financial, non-financial, intrinsic and extrinsic rewards, which are made available to an organisation's human resources (Armstrong \& Stephens, 2005; Tsede \& Kutin, 2013). Moreover, total rewards encapsulate all aspects of a job that employees perceive as valuable (WorldatWork, 2006). For the purpose of this study, total rewards are defined as the inclusion of all monetary and non-monetary returns (intrinsic and extrinsic rewards) that employees receive for investing their time, effort, energy, talents and results in their work (Armstrong \& Stephens, 2005; Hotz, 2014; WorldatWork, 2006).

From a talent perspective, total rewards' strategies have been found to contribute towards attracting, motivating and retaining valuable talent in the workplace (Bussin \& Toerien, 2015; Makhuzeni \& Barkhuizen, 2015; WorldatWork, 2006). While some researchers argued that total rewards have been used to improve organisational competitiveness in the rapidly changing global markets (Jiang et al., 2009), other scholars have recognised that total rewards may be used as a strategy to enhance employee engagement (Hotz, 2014; WorldatWork, 2006).

\section{Workplace trust}

Another important behavioural-related aspect that should not be overlooked in the retention of top talent is workplace trust (Chitsaz-Isfahani \& Boustani, 2014; Enguene, 2015; Hytter, 2007).

A commonly accepted definition of trust in literature is hard to find (Bagraim \& Hime, 2007; Bews \& Martins, 2002; Hakanen \& Soudunsaari, 2012). Trust is often defined in terms of one's vulnerability to the actions of others and that the belief in others' intentions and behaviours will lead to positive outcomes (Hakanen \& Soudunsaari, 2012; Kreitner \& Kinicki, 1995; Mayer, Davis \& Schoorman, 1995; O’Brien, 2001).

Ferres, Connell and Travaglione (2004) stated that corporate forms of trust can be classified within three dimensions, namely, trust in the organisation, trust in management and trust in co-workers. Bagraim and Hime (2007) stipulated that trust in the organisation constitutes a systems form of trust. Organisational trust thus entails the confidence that an individual has in the company itself rather than in a particular person or group of people (Galford \& Drapeau, 2002; Paliszkiewicz, 2011).

Trust in co-workers and in immediate management represents an interpersonal form of trust (Bagraim \& Hime, 2007; Galford \& Drapeau, 2002). Interpersonal trust is often regarded as the 'hallmark of effective relationships' (Dirks, 1999 , p. 3) or the 'social glue' of affiliations within an organisation (Abrams, Cross, Lesser \& Levin, 2003). It further refers to the perception that an individual has as to whether another person can be trusted under particular circumstances, either personally in their intentions, or in their attributes (Brown, Gray, McHardy \& Taylor, 2015; McKnight \& Chervany, 2001; Tan \& Lim, 2009).

Ample literature has identified the need to study trust within an organisational setting. Six, Nooteboom and Hoogendoorn (2010) argued that trust is an important aspect during change events and, as such, provides one with the 
ability to support change. The dynamics of trust and the potential value thereof can have a major influence on organisational functioning and behaviour. For instance, commitment and acknowledgement shown to organisational objectives and company values by employees, with a high degree of trust, tend to display more diligence and higher levels of productivity and innovation (Lyman, 2003; O'Brien, 2001; Sonnenberg, 1994).

Trust is, furthermore, seen to uphold cooperation within the workplace as it allows for the encouragement of information sharing, enhanced relationships amongst individuals and teams and enriches problem-solving and conflict resolution, which leads to better organisational performance (Brown et al., 2015; Lyman, 2003; Six et al., 2010).

\section{Work engagement}

Organisational rewards and workplace trust have been found to lead to an increase in work engagement (Engelbrecht, Heine \& Mahembe, 2014; Ram \& Prabhakar, 2011; Sundaray, 2011; Thirapatsakun, Kuntonbutr \& Mechinda, 2014). This study supports the commonly accepted definition by Schaufeli, Salanova, Gonzalez-Roma and Bakker (2002, p. 74) who define work engagement as the positive, fulfilling, work-related state of mind that is characterised by vigour, dedication and absorption'.

Vigour refers to elevated energy levels, the willingness to invest effort in one's work, one's mental resilience and one's persistence in the face of difficulties while dedication is a sense of enthusiasm, pride, inspiration and challenge (Altunel, Kocak \& Cankir, 2015; Schaufeli et al., 2002). Schaufeli and Bakker (2003) expressed vigour and dedication as the most important dimensions of work engagement. Absorption, on the contrary, is characterised by one being satisfied with and immersed in work to the extent to which the individual encounters an optimal experience (Bell \& Barkhuizen, 2011; Csikszentmihalyi, 1990).

Literature has shown that employees who are engaged in their work demonstrate higher levels of productivity, efficiency and a sense of personal accomplishment in their work, take initiative and persist with challenging and demanding tasks (Holbeche \& Matthews, 2012; Rothmann \& Jordaan, 2006). Furthermore, work engagement helps to boost employee motivation, morale, job satisfaction and psychological wellbeing. On the contrary, employees who are not engaged in their work tend to depict less commitment and are more likely to leave their organisation or quit their jobs (Hoole \& Bonnema, 2015; Rich, Lepine \& Crawford, 2010; Saks, 2006).

\section{The relationship between organisational rewards and workplace trust}

Research about the relationship between organisational rewards and workplace trust is infrequent, fairly outdated and fragmented. Burke (2002) suggested that extrinsic rewards may assist employees in developing trust. On the contrary, Tzafrir (2005) argued that managers are more likely and willing to increase compensation and incentive plans when they perceive their subordinates to be trustworthy.

The relationship between extrinsic rewards and workplace trust is not always optimistic. Fehr and List (2004) found that employees can perceive incentives as either hostile (negatively; as a threat or punishment) or as kind (positively; incentives given out of sincerity). When employees perceived their incentives in a more negative light, they were found to have a more harmful and unfavourable influence on certain behaviours such as reduced workplace trust. Similarly, Brown et al. (2015) argued that when organisations limit and reduce overtime pay, workplace trust may be weakened.

The relationship between intrinsic rewards and workplace trust has also been explored. In their study on selfdetermination in the workplace, Deci, Connell and Ryan (1989) reported that when managers were more supportive of autonomy amongst workgroups, employees reported higher levels of trust within organisations. Although not technically a reward, but useful to measure intrinsic rewards, Osmani, Zaidi and Nilashi (2014) argued that intrinsic motivation may lead to higher levels of trust within organisations. In addition, in Thomas's (2009) model of intrinsic rewards, trust is considered an important element which falls under the sense of choice dimension (which refers to one's ability to choose how work is accomplished, what work activities will be performed and a sense of ownership, independence and responsibility for workrelated outcomes).

Ferrin and Dirks (2004) noted that organisational rewards may have a strong and predictable influence on interpersonal trust. They suggested that rewards can influence trust by means of altering employees' perceptions about the motives of others and evaluate their behaviours based on reward structures. Organisational leaders, subordinates and rewards play an imperative role in establishing a climate of workplace trust. When subordinates can be perceived as trustworthy and valuable by their superiors, organisational leaders are more inclined to nourish and enhance their loyalty through the use of rewards (Philips, 1997). In light of outdated findings, the influence of organisational rewards on trust is not only fragmented but limited. The investigation of this relationship is thus an area of research, which needs further exploration, particularly within the South African context.

\section{The relationship between organisational rewards and work engagement}

A number of previous studies have found a positive relationship between organisational rewards and work engagement (Gill, Dugger \& Norton, 2014; Hulkko-Nyman et al., 2014; Jacobs et al., 2014; Masvaure, Ruggunan \& Maharaj, 2014; Sanhari, 2014; Yahya, Isa \& Johari, 2012; Zhijian \&Tianshu, 2013). 
While research demonstrated that extrinsic rewards lead to higher levels of work engagement, the social exchange theory further supports this relationship. This theory holds that when employees receive rewards and recognition for their efforts exerted on a job, they will participate in a fair exchange through responding with increased work engagement (Gujral \& Jain, 2013; Ram \& Prabhakar, 2011; Waqas \& Saleem, 2014).

In a South African study, Jacobs et al. (2014) found that when organisations provided employees with heightened intrinsic rewards, they were more engaged in their work. These results were consistent with those of Masvaure et al. (2014) who discovered that organisations whose employees were more intrinsically rewarded and driven demonstrated an increase in work engagement. In particular, intrinsic rewards and, more specifically, psychological meaningfulness were found to have a statistically strong relationship with employee engagement (May, Gilson \& Harter, 2004).

Roberts and Davenport (2002) articulated that a work environment that reaps more types of rewards for employees can lead to an increase in work engagement. In addition, Ram and Prabhakar (2011) found that through the use of both intrinsic and extrinsic rewards, employees were more engaged in their work. Although much of the research has highlighted that the use of intrinsic rewards may lead to higher levels of work engagement, the use of extrinsic rewards should not be overlooked in the exploration of drawing on both types of rewards to ensure that employees are more engaged in their work (Obicci, 2015; Ram \& Prabhakar, 2011; Roberts \& Davenport, 2002; WorldatWork, 2006).

\section{The relationship between workplace trust and work engagement}

Literature provides ample support indicating a positive relationship between workplace trust and employee engagement (Chughtai \& Buckley, 2008; Engelbrecht et al., 2014; Men, 2015; Mone \& London 2010; Ugwu, Onyishi \& Rodriguez-Sanchez, 2014).

Costigan, Ilter and Berman (1998) noted that when employees perceive their supervisors to be competent and supportive, they are more likely to trust their superiors when workplace issues arise. Similarly, Ugwu et al. (2014) discovered that workplace trust has a significant and strong positive relationship with work engagement. Research carried out by Chughtai and Buckley (2008) as well as Mone and London (2010) proposed that having a good degree of workplace trust can result in increased work engagement. Men (2015) confirmed this in his study in the United States, finding that the quality of employee-organisational relationships (including trust) positively influences engagement.

To conclude, organisational rewards (Bussin \& Toerien, 2015; Jacobs et al., 2014; Nujjoo \& Meyer, 2012), workplace trust (Krot \& Lewicka, 2012; Sousa-Lima, Michel \& Caetano, 2013) and work engagement (Bedarkar \& Pandita, 2014;
Beukes \& Botha, 2013) are important behavioural-related concepts within today's world of work. With high turnover rates and the poor global economic climate, these concepts are significant for behavioural practitioners who invest time and energy into improving their talent management strategies for the purpose of seeking to retain skilled and valuable employees.

\section{Problem statement and research questions}

Retaining a skilled workforce has become a major concern and challenge for many organisations, particularly within South Africa (Kerr-Phillips \& Thomas, 2009; Muteswa \& Ortlepp, 2011; Terera \& Ngirande, 2014; Visser 2012). Organisations are moving away from traditional organisational reward practices in which salaries, bonuses and other concrete benefits are no longer being used as the only means for motivating and retaining their employees (Jacobs et al., 2014). These rewards alone are no longer effective in establishing workplace trust and ensuring that employees will be more engaged in their work (Jacobs et al., 2014; Martins \& Von der Ohe, 2002; Scott et al., 2010).

It is, therefore, important that organisations aim to create favourable conditions for employees to reduce staff turnover and retain human capital. It is for this reason that South African organisations need to continually improve and better their talent management strategies by focusing on aspects such as organisational rewards to enhance workplace trust and work engagement. Against this background, the study sought to answer the following research questions:

- Question 1: Is there a relationship between organisational rewards, workplace trust and work engagement?

- Question 2: Do intrinsic rewards predict workplace trust and work engagement?

- Question 3: Do extrinsic rewards predict workplace trust and work engagement?

- Question 4: Do total rewards predict workplace trust and work engagement?

\section{Objectives of the study}

Research findings pertaining to organisational rewards, workplace trust and work engagement within the corporate South African context are limited. In addition, research is still largely growing as many gaps in the literature are prevalent. To contribute towards the body of knowledge through filling some of the recognised gaps, this research study primarily aimed to explore the relationship between organisational rewards, workplace trust and work engagement within the South African employment context. In addition, the research study sought to determine whether intrinsic and extrinsic organisational rewards predict workplace trust and work engagement.

\section{Conceptual model}

In light of the aforementioned problem statement, literature review and overall aims of the research study, Figure 1 


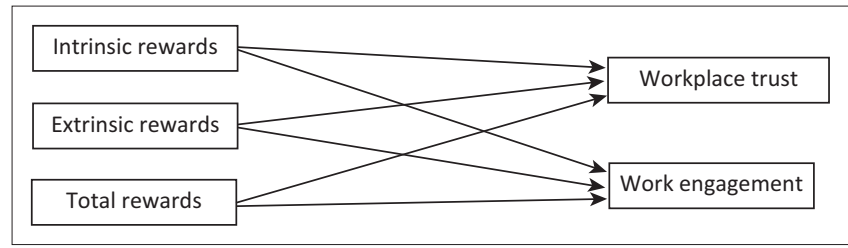

FIGURE 1: Conceptual model for the relationship between organisational rewards, workplace trust and work engagement.

demonstrates the conceptual model with regard to exploring whether there is a relationship between organisational rewards, workplace trust and work engagement and, additionally, to determine whether organisational rewards are able to predict workplace trust and work engagement.

\section{Research design}

A quantitative, exploratory, cross-sectional research design was employed. Participants were selected based on their availability and willingness to participate. To be included in the study and increase the validity of the results, participants must have had at least one full year of working experience, had completed Grade 12 and been able to complete the questionnaire in English.

This study sought to comprehensively investigate the relationship between the key constructs amongst a multitude of employees who acquire rewards and returns for their efforts exerted in their jobs. As such, the intention of the study was to make the sample as representative as possible through obtaining a target group consisting of both men and women, participants of all ages, races and home languages as well as having a vast range of years of working experience and education level. The findings generated from the sample can, therefore, contribute towards research in a multitude of industries, sectors and disciplines.

To collect data from the participants, a non-probability convenience sampling procedure was utilised. This sampling technique entails selecting participants from a target population based on the researcher's convenience and access to participants (Ross, 2005). In addition, this technique is used to select participants who are readily available to the researcher at the time of data collection (Zikmund, 2003). Advantages of utilising this technique include that it is less expensive than other techniques, less time-consuming and easier to utilise when obtaining participants.

A total of 350 questionnaires were distributed to employees in various industries and sectors within the Gauteng region. All necessary steps in line with ethical considerations were taken to ensure anonymity and confidentiality. After a data vetting process took place, the final random sample consisted of 251 South African employees $(N=251)$.

The final sample consisted of $42.6 \%$ men and $57.4 \%$ women. Their ages ranged between 17 and 72 years, with the majority of the participants falling into the 26-36 age category. The distribution with regard to ethnicity was black people $(n=55 ; 21.9 \%)$; mixed race $(n=16 ; 6.4 \%)$; Indian or Asian $(n=16 ; 6.4 \%)$; white people $(n=163 ; 64.9 \%)$ and other $(n=1 ; 0.4 \%)$. The three main language groups were English $(42.6 \%)$, Afrikaans (32.7\%) and isiZulu (13; 5.2\%). Regarding education, the majority of participants had a Grade 12 level education (36.3\%), followed by having a diploma or certificate $(25.5 \%)$ and a bachelor's degree (12.4\%). In terms of working experience, the distribution was more or less equal, representing 1-5 years' experience (24.3\%), 5-10 years $(26.7 \%), 10-20$ years (23.9\%) and $20+$ years of working experience $(25.1 \%)$. With regard to the industry that participants were currently employed in, the sample was well distributed.

\section{Measuring instruments}

The questionnaire consisted of seven measures including a demographic and biographical information section compiled by the researchers. To our knowledge, there is no strong instrument measuring extrinsic and intrinsic rewards available. The researchers, therefore, resorted in using different subscales to measure the different components of rewards; as was introduced in the literature review. The measures utilised in the questionnaire are briefly introduced.

\section{Extrinsic rewards}

Job Satisfaction Survey (JSS) was developed by Spector (1985). The JSS is designed to measure perceptions and attitudes regarding various aspects of an individuals' job. Four subscales comprising four items each were selected from this instrument, which included pay, promotion, fringe benefits and contingent rewards. Respondents were required to indicate their responses on a six-point Likert-type scale ranging from 1 (disagree very much) to 6 (agree very much). Examples of items include: 'I feel I am being paid a fair amount for the work I do' and 'I am satisfied with my chances for promotion'. Spector (1985) reported a Cronbach alpha reliability coefficient of 0.91 for the overall scale and coefficients of $0.75,0.73,0.73$ and 0.76 for the subscale scores, respectively. Within the South African research context, Lumley, Coetzee, Tladinyane and Ferreira (2011) reported satisfactory Cronbach alpha coefficients of $0.78,0.78,0.72$ and 0.76 , respectively.

\section{Intrinsic rewards}

Intrinsic Motivation Inventory (IMI) was developed by McAuley, Duncan and Tammen (1989). The IMI is designed to measure participants' subjective work-related experiences regarding intrinsic motivation. The interest or enjoyment subscale was selected from this instrument. This subscale comprised seven items, which were measured using a seven-point Likert-type scale. Respondents were required to indicate their responses ranging from 1 (not true at all) to 7 (very true). An example of an item includes: 'I enjoy doing this activity very much'. Previous studies yielded a Cronbach alpha reliability coefficient of 0.78 (McAuley et al., 1989) and 0.89 (Monteiro, Mata \& Peixoto, 2015). Within the 
South African context, Masvaure et al. (2014) reported an alpha coefficient of 0.75 .

Psychological Meaningfulness Scale (PMS) was developed by Spretizer (1995). The PMS is designed to assess psychological meaningfulness in the workplace. It consists of six items, which are measured on a five-point Likert-type scale and assess the degree to which individuals assign meaning to their job-related tasks. Responses range from 1 (totally agree) to 5 (totally disagree). Examples of items include: 'The work I do on this job is worthwhile', 'My job activities are important to me' and 'I feel that the work I do on this job is valuable'. This scale has frequently been used within the South African context, where acceptable Cronbach alpha coefficients have been reported. For instance, Williamson (2011) and Van Zyl, Deacon and Rothmann (2009) reported a reliability coefficient of 0.85, whereas Rothmann and Hamukang'andu (2013) reported a reliability coefficient of 0.67 .

Basic Psychological Needs at Work Scale (BPNWS) was developed by Deci and Ryan (2000). The BPNWS is designed to measure intrinsic need satisfaction in specific domains within one's life. To measure autonomy at work, the autonomy at work subscale was selected from this instrument. It consists of seven items that are measured on a seven-point Likert-type scale, with responses ranging from 1 (not true at all) to 7 (very true). Examples of items include: 'I feel pressurised at work' and 'When I am at work, I have to do what I am told'. In their study, Deci et al. (2001) reported a Cronbach alpha coefficient of 0.85 for the autonomy at work subscale. In a more recent study, Stäbler, De Boer and Rosema (2016) found an adequate reliability coefficient of 0.70. In addition, Coetzer (2014) found a Cronbach alpha coefficient of 0.82 within the South African pharmaceutical industry.

\section{Workplace trust}

Workplace Trust Survey (WTS) was developed by Ferres (2001). The WTS is designed to measure trust within organisations. It consists of 36 items that measure three subscales: namely, trust in organisations, trust in co-workers and trust in supervisors. These subscales comprise 12 items each, which are measured using a seven-point Likert-type scale ranging from 1 (strongly disagree) to 7 (strongly agree). Examples of items include: 'I feel that information can be shared openly', 'I believe that my manager follows promises through with action' and 'I think that my co-workers act reliably from one moment to the next'. A high measure of internal consistency was found by James (2011) who reported an alpha coefficient at 0.97 . Cronbach alpha reliability coefficients between 0.90 and 0.97 in both the South African and Australian context have further been reported (Ferres, 2001).

\section{Work engagement}

The Utrecht Work Engagement Scale (UWES - 17 item) was developed by Schaufeli et al. (2002). The UWES is designed to measure work engagement. It comprises 17 items that measure vigour, dedication and absorption (the three subscales of work engagement). To rate the items, a seven-point Likerttype scale is used, with responses ranging from 0 (never) to 6 (always). Examples of items include: 'At my work, I am bursting with energy', 'I find the work that I do full of meaning and purpose' and 'I am immersed in my work'. Research has shown that the UWES has satisfactory reliability. Cronbach alpha reliability coefficients have been reported at between 0.68 and 0.91 (Schaufeli et al., 2002). In a South Africa study, De Bruin, Hill, Henn and Muller (2013) found reliability coefficients of $0.88,0.91$ and 0.85 for the subscales.

\section{Statistical analysis}

The statistical analysis was carried out using SPSS version 22 (SPSS Inc., 2013). To analyse the data from the responses in the questionnaires, descriptive statistics (means, medians and standard deviations) and reliability tests utilising Cronbach alpha (Cronbach, 1951) for each scale were used to determine internal consistency, validity and homogeneity of the measuring instruments. Pearson's product-moment correlation and Cohen's effect size (Cohen, 1988) were selected to investigate the relationship between organisational rewards, workplace trust and work engagement. Standard multiple regression analysis was conducted to determine whether intrinsic rewards, extrinsic rewards and total rewards predicted workplace trust and work engagement.

\section{Results \\ Descriptive statistics}

To determine normal distribution and provide more information on the scales and instruments used, descriptive statistics were executed (see Table 1). The scales all fell well within the generally acceptable range of $<2$ and $<4$ (Finch \& West, 1997) and were all normally distributed.

Table 1 depicts the alpha coefficients and normality scores for the scales utilised. Most of the scales were found to be satisfactory in accordance with the guideline of $>0.70$ (Nunnally \& Bernstein, 1994). The highest reliabilities amongst the scales included trust in organisation $(\alpha=0.95)$, trust in supervisors $(\alpha=0.95)$ and trust in co-workers ( $\alpha=0.96$ ), followed by psychological meaningfulness $(\alpha=0.93)$. The scales that produced the lowest reliabilities included contingent rewards $(\alpha=0.59)$, fringe benefits $(\alpha=0.61)$ and promotion $(\alpha=0.62)$.

\section{Correlation analysis}

To answer the primary research question, Pearson's product-moment correlations were calculated (see Table 2).

The results indicated that extrinsic rewards have a statistically and practically significant relationship with intrinsic rewards ( $r=0.42 ; p<0.01$; medium effect), total rewards $(r=0.90 ; p<0.01$; large effect), workplace trust $(r=0.68 ; p<0.01$; large effect $)$ and work engagement $(r=0.34$; $p<0.01$; medium effect). It was further found that intrinsic rewards have a statistically and practically significant 
TABLE 1: Descriptive statistics of the organisational rewards, workplace trust and work engagement scales.

\begin{tabular}{|c|c|c|c|c|c|}
\hline Item & Mean & SD & Skewness & Kurtosis & $\alpha$ \\
\hline Pay & 13.66 & 4.59 & 0.05 & -0.40 & 0.70 \\
\hline Promotion & 13.70 & 4.18 & 0.08 & -0.36 & 0.62 \\
\hline Fringe benefits & 14.30 & 4.27 & 0.23 & -0.29 & 0.61 \\
\hline Contingent rewards & 14.62 & 4.22 & -0.03 & -0.19 & 0.59 \\
\hline Interest or enjoyment & 37.28 & 7.92 & -0.41 & -0.49 & 0.84 \\
\hline Psychological meaningfulness & 11.81 & 5.06 & -0.95 & 1.17 & 0.93 \\
\hline Autonomy & 24.05 & 4.99 & -0.13 & -0.13 & 0.66 \\
\hline Trust in organisations & 56.44 & 16.52 & -0.32 & -0.60 & 0.95 \\
\hline Trust in supervisors & 59.39 & 16.65 & -0.68 & -0.02 & 0.95 \\
\hline Trust in co-workers & 58.02 & 16.08 & -0.75 & 0.26 & 0.96 \\
\hline Work engagement & 72.62 & 17.81 & -0.60 & 0.06 & 0.93 \\
\hline Total extrinsic rewards & 59.79 & 13.69 & 0.28 & -0.10 & 0.82 \\
\hline Total intrinsic rewards & 73.27 & 9.42 & -0.03 & 0.12 & 0.65 \\
\hline Total rewards & 133.23 & 19.56 & 0.26 & -0.02 & 0.81 \\
\hline
\end{tabular}

TABLE 2: Correlation coefficients of organisational rewards, workplace trust and work engagement.

\begin{tabular}{lllll}
\hline Item & $\mathbf{1}$ & $\mathbf{2}$ & $\mathbf{3}$ & $\mathbf{4}$ \\
\hline Extrinsic rewards & 1.00 & - & - & - \\
Intrinsic rewards & $0.42^{* \mathrm{~b}}$ & 1.00 & - & - \\
Total rewards & $0.90^{* \mathrm{c}}$ & $0.77^{* \mathrm{c}}$ & 1.00 & - \\
Workplace trust & $0.68^{* \mathrm{c}}$ & $0.46^{* \mathrm{~b}}$ & $0.69^{* \mathrm{c}}$ & 1.00 \\
Work engagement & $0.34^{* \mathrm{~b}}$ & $0.53^{* \mathrm{c}}$ & $0.50^{* \mathrm{c}}$ & $0.52^{* \mathrm{c}}$ \\
\hline
\end{tabular}

Practically Significant correlation, $r>0.10$ (small effect).

b, Practically significant correlation, $r>0.30$ (medium effect); ', Practically significant correlation, $r>0.50$ (large effect).

*, Statistically significant correlation, $p<0.01$.

relationship with total rewards $(r=0.77 ; p<0.01$; large effect), workplace trust $(r=0.46 ; p<0.01$; medium effect $)$ and work engagement $(r=0.53 ; p<0.01$; large effect), whereas total rewards have a statistically and practically significant relationship with workplace trust $(r=0.69 ; p<0.01$; large effect) and work engagement ( $r=0.50 ; p<0.01$; large effect). Workplace trust produced a statistically and practically significant relationship with work engagement $(r=0.52$; $p<0.01$; large effect).

\section{Multiple regression analysis}

In response to the secondary research questions on whether intrinsic and extrinsic rewards can predict workplace trust and work engagement, multiple regression analysis (using the method proposed by Field, 2013) was utilised.

Table 3 summarises the regression analysis with extrinsic rewards, intrinsic rewards and total rewards as predictors of workplace trust. Intrinsic rewards were entered in Step 1 and proved to be a statistically significant predictor of workplace trust, explaining $21 \%$ of the variance in workplace trust. Extrinsic rewards were entered in Step 2 and was also shown to be a statistically significant predictor of workplace trust, explaining an additional $49 \%$ of the variance in the total model $[F(2.241)=118.41, p<0.001]$. The model demonstrated that extrinsic and intrinsic rewards combined explained $70 \%$ of the variance in workplace trust. Regarding total rewards as a predictor of workplace trust, this variable was excluded from the rest of the analysis as it did not explain any additional variance.
Table 4 summarises the regression analysis with intrinsic rewards, extrinsic rewards and total rewards as predictors of work engagement. Intrinsic rewards were entered in Step 1 and statistically significantly predicted work engagement, explaining $28 \%$ of the variance. Thereafter, extrinsic rewards were entered in Step 2 and also statistically significantly predicted work engagement, explaining an additional $29 \%$ of the variance of the total model $[F(2.241)=$ 51.44, $p<0.001]$. The model indicated that intrinsic and extrinsic rewards combined explained $57 \%$ of the variance of work engagement. Regarding total rewards as a predictor of work engagement, this variable was excluded from the rest of the analysis as it did not explain any additional variance.

\section{Discussion}

The study sought to explore the relationship between organisational rewards, workplace trust and work engagement within the South African employment context and also aimed to determine whether intrinsic and extrinsic organisational rewards were able to predict workplace trust and work engagement. The research results in accordance with the objectives of this study encapsulate what follows.

\section{The relationship between organisational rewards, workplace trust and work engagement}

The first objective of this research study was to determine whether there is a relationship between organisational rewards, workplace trust and work engagement. Results revealed that the relationship between extrinsic rewards and workplace trust produced a correlation of 0.68 (large effect). A correlation of 0.46 (medium effect) was found between intrinsic rewards and workplace trust. Regarding the correlation between total rewards and workplace trust, a correlation of 0.69 (large effect) was found. The results indicated that the relationship between both intrinsic and extrinsic rewards, as well as total rewards and workplace trust, was statistically significant. This is an encouraging result indicating that organisations can utilise their reward structures to improve their employees' trust and work engagement levels and ultimately have a positive effect on other outcomes such as productivity, performance, 
TABLE 3: Multiple regression of workplace trust as the dependent variable and intrinsic rewards, extrinsic rewards and total rewards as independent variables.

\begin{tabular}{|c|c|c|c|c|c|c|c|c|c|c|}
\hline \multirow[t]{2}{*}{ Model } & \multirow[t]{2}{*}{ Rewards } & \multicolumn{2}{|c|}{ Unstandardised coefficient } & \multirow{2}{*}{$\begin{array}{l}\text { Standardised } \\
\text { coefficient (Beta) }\end{array}$} & \multirow[t]{2}{*}{$t$} & \multirow[t]{2}{*}{$p$} & \multirow[t]{2}{*}{$F$} & \multirow[t]{2}{*}{$R$} & \multirow[t]{2}{*}{$R^{2}$} & \multirow[t]{2}{*}{$\Delta R^{2}$} \\
\hline & & B & SE & & & & & & & \\
\hline \multirow[t]{2}{*}{1} & Constant & 17.35 & 19.69 & - & 0.88 & 0.40 & 64.26 & 0.46 & 0.21 & 0.21 \\
\hline & Intrinsic rewards & 2.14 & 0.27 & 0.46 & 8.02 & $0.00 *$ & - & - & - & - \\
\hline \multirow[t]{3}{*}{2} & Constant & -11.36 & 15.95 & - & -0.71 & 0.48 & 136.57 & 0.70 & 0.50 & 0.49 \\
\hline & Intrinsic rewards & 0.99 & 0.24 & 0.21 & 4.20 & $0.00 *$ & - & - & - & - \\
\hline & Extrinsic rewards & 1.90 & 0.16 & 0.59 & 11.69 & $0.00 *$ & - & - & - & - \\
\hline
\end{tabular}

*, Statistically significant, $p<0.05$.

TABLE 4: Multiple regression of work engagement as dependent variable and intrinsic rewards, extrinsic rewards and total rewards as independent variables.

\begin{tabular}{|c|c|c|c|c|c|c|c|c|c|c|}
\hline \multirow[t]{2}{*}{ Model } & \multirow[t]{2}{*}{ Rewards } & \multicolumn{2}{|c|}{ Unstandardised coefficient } & \multirow{2}{*}{$\begin{array}{l}\text { Standardised } \\
\text { coefficient (Beta) }\end{array}$} & \multirow[t]{2}{*}{$t$} & \multirow[t]{2}{*}{$p$} & \multirow[t]{2}{*}{$F$} & \multirow[t]{2}{*}{$\boldsymbol{R}$} & \multirow[t]{2}{*}{$R^{2}$} & \multirow[t]{2}{*}{$\Delta R^{2}$} \\
\hline & & B & SE & & & & & & & \\
\hline \multirow[t]{2}{*}{1} & Constant & -0.93 & 7.58 & - & -0.12 & 0.90 & 95.75 & 0.53 & 0.28 & 0.28 \\
\hline & Intrinsic rewards & 1.00 & 0.10 & 0.53 & 9.79 & $0.00 *$ & - & - & - & - \\
\hline \multirow[t]{3}{*}{2} & Constant & -3.65 & 7.60 & - & -0.48 & 0.63 & 5.40 & 0.55 & 0.30 & 0.29 \\
\hline & Intrinsic rewards & 0.90 & 0.11 & 0.47 & 7.99 & $0.00 *$ & - & - & - & - \\
\hline & Extrinsic rewards & 0.18 & 0.08 & 0.14 & 2.32 & $0.02 *$ & - & - & - & - \\
\hline
\end{tabular}

*, Statistically significant, $p<0.05$.

organisational commitment and job satisfaction. The findings are in line with previous research reporting that organisational rewards are related to workplace trust (Burke, 2002; Engelbrecht et al., 2014; Fehr \& List, 2004; Ferrin \& Dirks, 2004; Gneezy, Meier \& Rey-Biel, 2011; Tzafrir, 2005; Van der Berg \& Martins, 2013).

One can, therefore, infer that higher levels of organisational rewards (intrinsic, extrinsic or both) imply a higher degree of workplace trust. A potential explanation of this finding is that organisations that promote a high trust climate are more likely to reward employee effort on the job through the use of intrinsic and extrinsic rewards. In particular, organisational leaders who trust their subordinates may be more likely to perceive them as valuable and, as such, take measures to nurture and develop their loyalty (Philips, 1997; Chen, Hwang \& Liu, 2012). Developing and nurturing employee loyalty may be generated intrinsically through providing employees with meaningful work, autonomy and tasks, which reap interest or enjoyment and extrinsically through providing employees with recognition and through rewarding exceptional performance by means of increasing pay, promoting employees and providing them with higher levels of fringe and contingent rewards and other benefits. Another possible explanation of this relationship may be that employees who have high levels of trust in their supervisors, co-workers and organisation may be more productive (Sonnenberg, 1994). This can further signify higher extrinsic rewards (such as pay increases) as a result of heightened productivity and being appraised on a performance basis (Njanja, Maina, Kibet \& Njagi, 2013).

\section{The relationship between organisational rewards and work engagement}

The relationship between organisational rewards and work engagement has extensively been explored (Hotz, 2014; Hulkko-Nyman et al., 2014; Jacobs et al., 2014; May et al., 2004; Rothmann \& Rothmann, 2010; Schaufeli \& Bakker, 2003; Thomas, 2009; Zhijian \& Tianshu, 2013). The findings in this study demonstrated that different types of organisational rewards, both extrinsic and intrinsic, have a statistically and practically positive relationship with work engagement. These findings support previous research, which found similar results (Jacobs et al., 2014; May et al., 2004; Rothmann \& Rothmann, 2010; Schaufeli \& Bakker, 2003; Thomas, 2009).

In addition, a statistical significant correlation between total rewards and work engagement was reported, providing further support to previous findings (Hotz, 2014; Ram \& Prabhakar, 2011; WorldatWork, 2006).

Based on the result, it can be potentially inferred that the higher the organisational reward (intrinsic and extrinsic), the more engaged employees will be in their work. Interestingly, similar to the findings of Schaufeli and Bakker (2003) and Thomas (2009), intrinsic rewards produced the highest correlation with regard to work engagement. When employees are provided with higher levels of intrinsic rewards, they tend to exert more effort, dedication and involvement in their work.

\section{The relationship between workplace trust and work engagement}

As outlined in the literature review, many authors support the idea that workplace trust and work engagement are related (Chughtai \& Buckley, 2008; Engelbrecht et al., 2014; Ferrin \& Dirks, 2004; Hassan \& Ahmed, 2011; Men, 2015; Mone \& London, 2010; Ugwu et al., 2014). In the current study, a statistically significant correlation (large effect) was found between workplace trust and work engagement. This implies that the higher employees' level of workplace trust is, the higher their level of engagement in their work would be.

This may be due to employees perceiving that there are additional resources such as support and instrumental assistance available to them, which they could potentially draw upon when needed. For example, when employees perceive their superiors to be competent, they are likely to possess more trust, confidence in and reliance on them when and if job-related challenges do arise (Chughtai \& Buckley, 
2008; Costigan et al., 1998). This highlights that potential future research can explore the influence that various other job characteristics, such as work resources, may have on the relationship between workplace trust and work engagement.

\section{Organisational rewards as predictors of workplace trust}

The secondary aim of this study was to determine the predictive significance of organisational rewards on workplace trust and work engagement.

Results indicated that both intrinsic and extrinsic rewards significantly predicted workplace trust. Intrinsic rewards explained $21 \%$ of the variance in workplace trust and adding extrinsic rewards, an additional $49 \%$ of the variance was explained. The results highlight the importance of ensuring adequate reward structures to ensure a trusting working environment.

Ferrin and Dirks (2004) observed that organisational rewards can have a strong and predictable influence on workplace trust and in particular, interpersonal trust, as rewards can influence trust by means of altering an employee's perception about the motives of others and subsequently evaluate their behaviours based on reward structures.

Tzafrir (2005) found that when superiors perceived their subordinates to be trustworthy, they were willing, and thus, more likely to increase employee compensation and incentive plans. From an employee's perspective, Fehr and List (2004) found that if employees perceive their extrinsic rewards in a more negative light, their incentives may reap a negative influence on certain behaviours, one of them being a decline in trust. From this finding, it can be potentially inferred that when employees perceive their extrinsic rewards in a more optimistic light, a positive influence on trust can be generated.

\section{Organisational rewards as predictors of work engagement}

The final objective of this research study was to determine whether organisational rewards were able to predict work engagement. Similar to workplace trust, the results demonstrated that both intrinsic and extrinsic rewards significantly predicted work engagement. Intrinsic rewards explained $28 \%$ of the variance, and extrinsic rewards explained an additional $29 \%$ of the variance.

The results were in line with previous findings, which suggested that organisational rewards can predict work engagement (Gujral \& Jain, 2013; Maslach, Schaufeli \& Leiter, 2001; May et al., 2004; Ram \& Prabhakar, 2011; Roberts \& Davenport, 2002; WorldatWork, 2006). Some evidence suggests that employees are more inclined to be engaged in their work when placing high value on intrinsic rewards and when they perceive and feel that that the organisation 'cares' about them at work (Obicci, 2015; Ozütku, 2012; Silverman, 2004).
In terms of extrinsic rewards, employees who feel rewarded and recognised for their efforts may feel more satisfied and, therefore, exert more effort and engagement in their work (Waqas \& Saleem, 2014). The social exchange theory supports this result, which holds that when employees are rewarded for their work efforts, they participate in an exchange of providing their organisation with increased work engagement (Gujral \& Jain, 2013). In light of both rewards, a rewarding work environment can help employees to be more engaged at work (Roberts \& Davenport, 2002).

\section{Limitations}

Throughout this study, several limitations were identified. Firstly, the cross-sectional research design may serve as a limitation as it makes it difficult to determine causal inferences about the relationships between the three constructs. Secondly, to collect data from participants, the collection method relied exclusively on self-report measures. The utilisation of this method could potentially lead to social desirability bias as respondents may have had the tendency to respond in a more socially acceptable and positive light. Thirdly, the sample size was relatively small $(n=251)$ and data were only collected within the Gauteng region. This may have limited the generalisability of the findings. The fourth limitation of the study encapsulates the relatively low reliabilities of the promotion, fringe benefits and contingent rewards subscales used to measure extrinsic rewards. Particularly, the alpha coefficients did not meet the intended cut-off value of $>0.70$. A possible explanation for this could be that these variables were measured using subscales adapted from the JSS and only contained four items each. The final limitation regards the scales utilised to measure organisational rewards. Unfortunately, access to instruments for measuring both intrinsic and extrinsic rewards proved challenging. Limited rewards instruments are available.

\section{Recommendations}

In light of the findings, conclusions and limitations of this particular study, a number of possible recommendations for future research may be made. A significant recommendation would be to acquire a larger sample size from a vast array of demographical regions to generalise the findings to the broader South African context. Furthermore, a longitudinal study could be employed to determine whether the relationships between organisational rewards, workplace trust and work engagement remain stable across time. This could further include looking at the correlations and regressions between the subscales of workplace trust and work engagement, individually, to determine with more accuracy, the particular factors that are related to and predict these two constructs.

In addition, it is recommended that the impact that organisational rewards have on other variables such as job satisfaction, employee loyalty, motivation and commitment be explored as these could prove useful and valuable within the talent management domain. It might also be valuable and 
interesting to determine whether additional factors such as gender and age moderate this relationship. The final recommendation for this study would be to develop and validate instruments for the measurement of both intrinsic and extrinsic rewards that can ultimately be made readily available to researchers, academics and scholars within the management and behavioural sciences. As such, the above recommendations would prove valuable to human resources practitioners and industrial psychologists who wish to better their current employee strategies.

\section{Practical implications}

The study proved useful in that it provided insight into the influence that organisational rewards may have on workplace trust and work engagement. As outlined earlier in the study, these variables all play a substantial role in retaining employees. These findings are significant in that they may contribute towards improving talent management strategies, particularly, within volatile and competitive business environments, where organisations are faced with the challenge of retaining employees who fall within a scarce talent pool.

The study provided insight into the amount of interest and value that employees place on organisational rewards in their pursuit of seeking trust in their supervisors, co-workers and organisations as well as in engaging in their work. The study thus not only contributed to the existing body of knowledge but also provided significant findings, which could assist scholars, researchers and managers in better understanding the relationship between organisational rewards, workplace trust and work engagement as well. Furthermore, the findings provided a platform for future researchers to explore these relationships more intricately.

\section{Conclusion}

This study found that in the 21st century world of work, although extrinsic rewards are important to heighten trust and engagement within the workplace, intrinsic rewards should not be overlooked, as the modern workforce is increasingly intrinsically driven. In particular, a moderate-tostrong positive relationship was found between rewards, trust and work engagement, and that rewards (and more so, intrinsic rewards) were able to predict workplace trust and work engagement.

The significance of exploring organisational rewards is that, in previous years, research found a link to various outcomes such as employee loyalty, performance and job satisfaction. With high turnover rates and poor economic conditions, reward practices have been in the spotlight due to organisations drastically cutting down on their costs and expenditure. This has further led to a reduction in outcomes such as in the levels of both engagement and confidence that employees portray at work. Over the past few years, linking organisational rewards with workplace trust and work engagement has thus become significant. Through exploring the influence that rewards might have on trust and engagement in the workplace, this study further provided relevant insight into how management and other behavioural specialists could make use of tangible, non-tangible and psychological rewards to enhance human-related strategies for the purpose of heightening employee retention within the modern world of work.

\section{Acknowledgements Competing interests}

The authors declare that they have no financial or personal relationships that may have inappropriately influenced them in writing this article.

\section{Authors' contributions}

C.H. was the supervisor of the research study. She was responsible for making conceptual contributions to the study, data analysis and writing of the article. J.V. was responsible for conceptual contributions to the study; she was the main contributor to the literature review and was responsible for data collection, data capturing and some statistical analyses.

\section{References}

Abrams, L.C., Cross, R., Lesser, E., \& Levin, D.Z. (2003). Nurturing interpersonal trust in knowledge-sharing networks. Academy of Management Executive, 17(4), 64-77. https://doi.org/10.5465/AME.2003.11851845

Aktar, S., Sachu, M.K., \& Ali, E. (2012). The impact of rewards on employee performance in commercial banks of Bangladesh: An empirical study. IOSR Journal of Business and Management, 6(2), 9-15. https://doi.org/10.9790/487X0620915

Altunel, M.C., Kocak, O.E., \& Cankir, B. (2015). The effect of job resources on work engagement: A study on Academicians in Turkey. Educational Sciences: Theory \& Practice, 15(2), 409-417. https://doi.org/10.12738/estp.2015.2.2349

Armstrong, M., \& Stephens, T. (2005). A handbook of employee reward management and practice. London: Kogan Page Limited.

Arnolds, C.A., \& Venter, D.J.L. (2007). The strategic importance of motivational rewards for lower-level employees in the manufacturing and retailing industries. South African Journal of Industrial Psychology, 33(3), 15-23. https://doi. org/10.4102/sajip.v33i3.390

Aslam, A., Ghaffar, A., Talha, T., \& Mushtaq, H. (2015). Impact of compensation and reward system on the performance of an organization: An empirical study on
banking sector of Pakistan. European Journal of Business and Social Sciences, 4(8), banking sector of Pakistan. European Journal of Business and Social Sciences, 4(8), aspx-/

Bagraim, J.J., \& Hime, P. (2007). The dimensionality of workplace interpersonal trust and its relationship to workplace affective commitment. South African Journal of and its relationship to workplace affective commitment. South African Journal
Industrial Psychology, 33(3), 43-48. https://doi.org/10.4102/sajip.v33i3.394

Balakrishnan, C., Masthan, D., \& Chandra, V. (2013). Employee retention through employee engagement: A study at an Indian international airport. Internationa Journal of Business and Management Invention, 2(8), 9-16. Retrieved August 15, 2015, from http://www.ijbmi.org/papers/Vol(2)8/Version-2/B028209016.pdf

Bedarkar, M., \& Pandita, D. (2014). A study on the drivers of employee engagement impacting employee performance. Procedia - Social and Behavioral Sciences, 133, 106-115. https://doi.org/10.1016/j.sbspro.2014.04.174

Bell, E., \& Barkhuizen, N. (2011). The relationship between barriers to change and the work engagement of employees in a South African property management company. South African Journal of Industrial Psychology, 37(1), 1-11. https://doi. org/10.4102/sajip.v37i1.935

Beukes, I., \& Botha, E. (2013). Organisational commitment, work engagement and meaning of work of nursing staff in hospitals. South African Journal of Industrial Psychology, 39(2), 1-10. https://doi.org/10.4102/sajip.v39i2.1144

Bews, N., \& Martins, N. (2002). An evaluation of the facilitators of trustworthiness. South African Journal of Industrial Psychology, 28(4), 14-19. https://doi. org/10.4102/sajip.v28i4.70

Bowen, R.B. (2000). Recognizing and rewarding employees. New York: McGraw-Hill.

Bratton, J., \& Gold, J. (2003). Human resource management: Theory and practice. New York: Palgrave MacMillan.

Brown, S., Gray, D., McHardy, J., \& Taylor, K. (2015). Employee trust and workplace performance. Journal of Economic Behavior \& Organization, 116, 361-378. https://doi.org/10.1016/j.jebo.2015.05.001 
Burke, W.W. (2002). Organizational change: Theory and practice. Thousand Oaks, CA: Sage.

Bussin, M., \& Toerien, W.C. (2015). Influence of reward preferences in attracting, retaining, and motivating knowledge workers in South African information technology companies. Acta Commercii, 15(1), 1-13. https://doi.org/10.4102/ ac.v15i1.290

Bussin, M., \& Van Rooy, D.J. (2014). Total rewards strategy for a multigenerational workforce in a financial institution. South African Journal of Human Resource Management, 12(1), 1-11. https://doi.org/10.4102/sajhrm.v12i1.606

Byars, L.L., \& Rue, L.W. (2011). Human Resource Management. (10th edn.). New York: McGraw-Hill.

Chen, T., Hwang, S., \& Liu, Y. (2012). Antecedents of the voluntary performance of employees: Clarifying the roles of employee satisfaction and trust. Public Personnel Management, 41(3), 407-420. https://doi.org/10.1177/00910260 1204100302

Chitsaz-Isfahani, A., \& Boustani, H. (2014). Effects of talent management on employee retention: The mediate effect of organizational trust. International Journal of Academic Research in Economics and Management Sciences, 3(5), 114-128. https://doi.org/10.6007/IJAREMS/v3-i5/1196

Chughtai, A., \& Buckley, F. (2008). Work engagement and its relationship with state and trait trust: A conceptual analysis. Journal of Behavioural and Applied Management, 10(1), 47-71. Retrieved July 02, 2015, from http://www.ibam.com/ pubs/jbam/articles/vol10/no1/JBAM_10_1_3.pdf

Coetzer, C. (2014). Work-related basic need satisfaction and flourishing of employees in a corporate pharmacy environment. Unpublished master's dissertation, North West University, North West, South Africa.

Cohen, J. (1988). Statistical power analysis for the behavioral sciences. (2nd edn.) Hillsdale, NJ: Lawrence Erlbaum.

Costigan, R.D., Ilter, S.S., \& Berman, J.J. (1998). A multidimensional study of trust in organizations. Journal of Managerial Issues, 10(3), 303-317. Retrieved Septembe 18, 2015, from http://www.ooa.nl/download/?id=16102599

Cronbach, L.J. (1951). Coefficient alpha and the internal structure of tests. Psychometrika, 16, 297-334. https://doi.org/10.1007/BF02310555

Csikszentmihalyi, M. (1990). Flow: The psychology of optimal experience. New York: Harper and Row.

De Bruin, D.P., Hill, C., Henn, C., \& Muller, K. (2013). Dimensionality of the UWES-17: An item response modelling analysis. South African Journal of Industria Psychology, 39(2), 1-8. https://doi.org/10.4102/sajip.v39i2.1148

Deci, E.L., Connell, J.E., \& Ryan, R.M. (1989). Self-determination in a work organization Journal of Applied Psychology, 74(4), 580-590. Retrieved July 09, 2015, from http://selfdeterminationtheory.org/SDT/documents/1989_DeciConnellRyan.pdf

Deci, E.L., \& Ryan, R.M. (2000). The what and why of goal pursuits: Human needs and the self-determination of behavior. Psychological Inquiry, 11, 227-268. https:// doi.org/10.1207/S15327965PLI1104_01

Deci, E.L., Ryan, R.M., Gagné, M., Leone, D.R., Usunov, J., \& Kornazheva, B.P. (2001) Need satisfaction, motivation, and well-being in the work organizations of a former Eastern Bloc country. Personality and Social Psychology Bulletin, 27, 930-942. https://doi.org/10.1177/0146167201278002

Dirks, K.T. (1999). The effects of interpersonal trust on work group performance Journal of Applied Psychology, 84, 445-455. https://doi.org/10.1037/00219010.84.3.445

Engelbrecht, A.S., Heine, G., \& Mahembe, B. (2014). The influence of ethical leadership on trust and work engagement: An exploratory study. South African Journal of Industrial Psychology, 40(1), 1-9. https://doi.org/10.4102/sajip.v40i1.1210

Enguene, T. (2015). Trust in the workplace: A permanent challenge for performance in an organization. International Journal of Management and Commerce Innovations, download.php?file=Trust $\% 20$ in $\% 20$ the $\% 20$ Workplace- 1933 .pdf\&act=book

Fehr, E., \& List, J.A. (2004). The hidden costs and returns of incentives - Trust and trustworthiness among CEOs. Journal of the European Economic Association, 2(5), 743-771. https://doi.org/10.1162/1542476042782297

Ferres, N. (2001). The development and validation of the workplace trust survey (WTS). Combining quantitative and qualitative methodologies. Unpublished master's dissertation, University of New Castle, New Castle, Australia.

Ferres, N., Connell, J., \& Travaglione, A. (2004). Co-worker trust as a social catalyst for constructive employee attitudes. Journal of Managerial Psychology, 19(6), 608-622. https://doi.org/10.1108/02683940410551516

Ferrin, D.L., \& Dirks, K.T. (2004). The use of rewards to increase and decrease trust: Mediating processes and differential effects. Organisation Science, 14(1), 18-31. https://doi.org/10.1287/orsc.14.1.18.12809

Field, A. (2013). Discovering statistics using IBM SPSS statistics. (4th edn.). London: Sage Publications.

Finch, J.F., \& West, S.G. (1997). The investigation of personality structure: Statistical models. Journal of Research in Personality, 31, 439-485. https://doi.org/10.1006/ jrpe.1997.2194

Galford, R.M., \& Drapeau, A.S. (2002). The trusted leader: Bringing out the best in your people and your company. New York: Free Press.

Gill, P.S., Dugger, J., \& Norton, F. (2014). The relationship between compensation and selected dimensions of employee engagement in a mid-sized engineering services firm. The Journal of Technology, Management, and Applied Engineering, 30(1). Retrieved July 02, 2015, from http://c.ymcdn.com/sites/www.atmae.org/ Retrieved July 02, 2015, from http://c.ymcdn.com/sile
resource/resmgr/articles/gill-dugger-norton-srelations.pdf
Gneezy, U., Meier, S., \& Rey-Biel, P. (2011). When and why incentives (don't) work to modify behaviour. Journal of Economic Perspectives, 25(4), 191-210. https://doi. modify behaviour. Journa

Gujral, H.K., \& Jain, I. (2013). Determinants and outcomes of employee engagement: A comparative study in information technology (IT) sector. International Journal of Advanced Research in Management and Social Sciences, 2(5), 207-220. Retrieved August 11, 2015, from http://www.garph.co.uk/IJARMSS/ May2013/16.pdf

Hafiza, N.S., Shah, S.S., Jamsheed, H., \& Zaman, K. (2011). Relationship between rewards and employee's motivation in the non-profit organizations of Pakistan. Business Intelligence Journal, 4(2), 327-334. Retrieved September 18, 2015, from http://saycocorporativo.com/saycoUK/BIJ/journal/Vol4No2/ 18, 2015, from
Article_11.pdf

Haider, M., Aamir, A., Hamid, A.A., \& Hashim, M. (2015). A literature analysis on the importance of non-financial rewards for employees' job satisfaction. Abasyn Journal of Social Sciences, 8(2), 341-354. Retrieved September 18, 2015, from http://www.aupc.info/wp-content/uploads/2015/12/V812-10.pdf

Hakanen, M., \& Soudunsaari, A. (2012). Building trust in high-performing teams. Technology Innovation Management Review, 38-41. Retrieved October 18, 2015 from https://timreview.ca/sites/default/files/article_PDF/HakanenSoudunsaari TIMReview_June2012.pdf

Hamukwaya, S.I., \& Yazdanifard, R. (2014). How a proper performance related reward system can contribute to work performance excellence. Open Journal of Busines and Management, 2, 189-194. https://doi.org/10.4236/ojbm.2014.23023

Harackiewicz, J.M., \& Hulleman, C.S. (2010). The importance of interest: The role of achievement goals and task values in promoting the development of interest. Journal of Educational Psychology, 102, 880-895. https://doi.org/10. 1111/j.1751-9004.2009.00207.x

Hassan, A., \& Ahmed, F. (2011). Authentic leadership, trust and work engagement International Journal of Social, Behavioral, Educational, Economic, Business and Industrial Engineering, 5(8), 1036-1042. https://doi.org/10.1504/JGBA.2013. 053568

Holbeche, L., \& Matthews, G. (2012). Engaged: Unleashing your organization's potential through employee engagement. Chichester: Wiley.

Hoole, C., \& Bonnema, J. (2015). Work engagement and meaningful work across generational cohorts. South African Journal of Human Resource Management 13(1), 1-11. https://doi.org/10.4102/sajhrm.v13i1.681

Hotz, G.J. (2014). The impact of a total rewards system on work engagement Unpublished master's dissertation, University of Johannesburg, Johannesburg, South Africa.

Hulkko-Nyman, K., Sarti, D., Hakonen, A., \& Sweins, C. (2014). Total rewards perceptions and work engagement in elder-care organizations: Findings from Finland and Italy. International Studies of Management \& Organization, 42(1), 24-49. https://doi.org/10.2753/IM00020-8825420102

Hytter, A. (2007). Retention strategies in France and Sweden. The Irish Journal of Management, 28(1), 59-79. Retrieved July 16, 2015, from http://urn.kb.se/resolv e?urn=urn:nbn:se:vxu:diva-2822

International Labour Office. (2006). Working time in the twenty-first century. Geneva, Switzerland: International Labour Organization.

Jacobs, S., Renard, M., \& Snelgar, R.J. (2014). Intrinsic rewards and work engagement in the South African retail industry. South African Journal of Industrial Psychology 40(2), 1-13. https://doi.org/10.4102/sajip.v40i2.119

James, L.J. (2011). The relationship between perceived organisational support and workplace trust: An exploratory study. Unpublished master's dissertation, University of the Western Cape, Cape Town, South Africa.

Jiang, Z., Xiao, Q., Qi, H., \& Xiao, L. (2009). Total reward strategy: A human resources management strategy going with the trend of the times. International Journal of Business and Management, 4(11), 177-183. https://doi.org/10.5539/ijbm. v4n11p177

Kerr-Phillips, B., \& Thomas, A. (2009). Macro and micro challenges for talent retention in South Africa. South African Journal of Human Resource Management, 7(1), 82-91. https://doi.org/10.4102/sajhrm.v7i1.157

Kimutai, K.A., \& Sakataka, W. (2015). Effect of reward on employee engagement and commitment at Rift Valley Bottlers Company. International Academic Journal of Human Resource and Business Administration, 1(5), 36-54. Retrieved July 15, Human Resource and Business Administration, 1(5), 36-54. Retrieved
2015, from http://www.iajournals.org/articles/iajhrba_v1_i5_36 54.pdf

Kompaso, S.M., \& Sridevi, M.S. (2010). Employee engagement: The key to improving performance. International Journal of Business and Management, 5(12), 89-96. https://doi.org/10.5539/ijbm.v5n12p89

Kreitner, R., \& Kinicki, A. (1995). Organizational behaviour. Chicago, IL: Irwin.

Krot, K., \& Lewicka, D. (2012). The importance of trust in manager-employee relationships. International Journal of Electronic Business Management, 10(3) 224-233. Retrieved July 17, 2015, from http://ijebm.ie.nthu.edu.tw/ijebm_web/ ijebm_static/Paper-V10_N3/A06.pdf

Kshirsagar, M., \& Waghale, V.Y. (2014). Impact of financial and nonfinancial rewards on employee motivation. International Research Journal of Management and Commerce, 1(6), 61-74. Retrieved October 15, 2015, from https://www.aarf.asia/ download.php?filename=77UiVAPXm0xs459.pdf\&new=

Kuptsch, C., \& Pang, E.F. (2006). Competing for global talent. Geneva, Switzerland: International Labour Organization.

Kwenin, D.O., Muathe, S., \& Nzulwa, R. (2013). The influence of employee rewards, human resource policies and job satisfaction on the retention of employees in Vodafone Ghana Limited. European Journal of Business and Management, 5(12), 13-20. Retrieved 14 October, 2015, from http://www.iiste.org/Journals/index. php/EJBM/article/view/5812/5879 
Lumley, E.J., Coetzee, m., Tladinyane, R., \& Ferreira, N. (2011). Exploring the job satisfaction and organisational commitment of employees in the information technology environment. Southern African Business Review, 15(1), 100-118. Retrieved August 10, 2015, from http://www.unisa.ac.za/contents/faculties/ service_dept/docs/SABVIEW_15_1_chap\%205.pdf

Lyman, A. (2003). Building trust in the workplace: Why trust brings out the best in your employees. Strategic HR Review, 3(1), 24-27. Retrieved October 17, 2015, from http://thepeoplegroup.com/wp-content/uploads/2008/04/article-buildingtrust-in-the-workplace.pdf

Makhuzeni, B., \& Barkhuizen, E.N. (2015). The effect of a total rewards strategy on school teachers' retention. South African Journal of Human Resource Management, 13(1), 1-10. https://doi.org/10.4102/sajhrm.v13i1.699

Malhorta, N., Budhwar, P., \& Prowse, P. (2007). Linking rewards to commitment: An empirical investigation of four UK call centres. International Journal of Human
Resource Management, 18(12), 2095-2017. https://doi.org/10.1080/ 09585190701695267

Martins, N., \& Von der Ohe, H. (2002). Trust as a factor in determining how to attract, motivate and retain talent. South African Journal of Industrial Psychology, 28(4), 49-57. Retrieved August 02, 2015, from http://www.sajip.co.za/index.php/sajip/ article/viewFile/79/76

Maslach, C., Schaufeli, W.B., \& Leiter, M.P. (2001). Job burnout. Annual Review of Psychology, 52, 397-422. https://doi.org/10.1146/annurev.psych.52.1.397

Masvaure, P., Ruggunan, S., \& Maharaj, A. (2014). Work engagement, intrinsic motivation and job satisfaction among employees of a diamond mining company in Zimbabwe. Journal of Economics \& Behavioral Studies, 6(6), 488-499. Retrieved September 03, 2015, from http://ifrnd.org/Research\%20Papers/J6(6)6.pdf

May, D.R., Gilson, R.L., \& Harter, L.M. (2004). The psychological conditions of meaningfulness, safety and availability and the engagement of the human spirit at work. Journal of Occupational and Organizational Psychology, 77(1), 11-37. https://doi.org/10.1348/096317904322915892

Mayer, R.C., Davis, H.D., \& Schoorman, F.D. (1995). An integrative model of organizational trust. Academy of Management Review, 20(3), 709-734. https:// organizational trust. Academy of Manag
doi.org/10.5465/AMR.1995.9508080335

McAuley, E., Duncan, T., \& Tammen, V.V. (1989). Psychometric properties of the Intrinsic Motivation Inventory in a competitive sport setting: A confirmatory factor analysis. Research Quarterly for Exercise and Sport, 60, 48-58. https://doi.org/10. analysis. Research Quarterly for

McKnight, D.H., \& Chervany, N.L. (2001). Trust and distrust definitions: One bite at a time. In R. Falcone, M. Singh, \& Y.H. Tan (Eds.), Trust in cyber-societies: Integrating the human and artificial perspectives (pp. 27-54). Berlin, Germany: Springer.

Men, L.R. (2015). Employee engagement in relation to employee - Organization relationships and internal reputation: Effects of leadership communication. Public Relations Journal, 9(2). Retrieved October 16, 2015, from http://www.prsa.org/ Intelligence/PRJournal/Vol9/No2/

Mone, E., \& London, M. (2010). Employee engagement through effective performance management: A practical guide for managers. New York: Routledge.

Monteiro, V., Mata, L., \& Peixoto, F. (2015). Intrinsic motivation inventory: Psychometric properties in the context of first language and mathematics learning. Psychology/Psicologia: Refl exão e Crítica, 28(3), 434-443. https://doi. org/10.1590/1678-7153.201528302

Mottaz, C.J. (1985). The relative importance of intrinsic and extrinsic rewards as determinants of work satisfaction. The Sociological Quarterly, 26(3), 365-385. https://doi.org/10.1111/j.1533-8525.1985.tb00233.x

Muteswa, R., \& Ortlepp, K. (2011). Contributing factors to potential turnover in a sample of South African management-level employees. Acta Commercii, 11, 1329. https://doi.org/10.4102/ac.v11i1.144

Nazir, T., Shah, S.F.H., \& Zaman, K. (2012). Literature review on total rewards: An international perspective. African Journal of Business Management, 6, 3046-3058.

Njanja, W.L., Maina, R.N., Kibet, L.K., \& Njagi, K. (2013). Effect of reward on employee performance: A case of Kenya Power and Lighting Company Ltd., Nakuru, Kenya. International Journal of Business and Management, 8(21), 41-49. https://doi. org/10.5539/ijbm.v8n21p41

Nujjoo, A., \& Meyer, I. (2012). The relative importance of different types of rewards for employee motivation and commitment in South Africa. South African Journal of Human Resource Management, 10(2), 1-10. https://doi.org/10.4102/sajhrm. v10i2.442

Nunnally, J.C., \& Bernstein, I.H. (1994). Psychometric theory. (3rd edn.). New York: McGraw-Hill.

Nyaga, J.W. (2015). Non financial reward and employee retention in private primary schools in Kenya (Kiambu County). International Journal of Management and Commerce Innovations, 3(1), 240-254. Retrieved Octobe 18,2015 , from https://www.google.co.za/url?sa=t\&rct=j\&q=\&esrc=s\&source= web\&cd $=2 \&$ cad $=$ rja\&uact $=8 \&$ ved $=0$ ahUKEwjyooSz2 bfSAhUJAcAKHZSdAGMO FggnMAE\&url=http $\% 3 \mathrm{~A} \% 2 \mathrm{~F} \% 2 \mathrm{Fw} w \mathrm{w}$.researchpublish.com $\% 2$ Fdownload.ph p $\% 3$ Ffile $\% 3$ DNon $\% 2520$ Financial $\% 2520$ Reward $\% 2520$ and $\% 2520$ Employee $\%$ 2520Retention-1746.pdf\%26act\%3Dbook\&usg=AFQjCNHjLbZ2V6GdSu6riqW 3TnEAZeGQ-w\&bvm=bv.148747831,bs.2,d.d2s

Obicci, P.A. (2015). Influence of extrinsic and intrinsic rewards on employee engagement (empirical study in public sector of Uganda). Management Studies and Economic Systems, 2(1), 59-70. Retrieved September 18, 2015, from http:// works.bepress.com/cgi/viewcontent.cgi?article=1019\&context=pa_obicci

O'Brien, R. (2001). Trust: Releasing the energy to succeed. Chichester: Wiley.

Omollo, P.A., \& Oloko, M.A. (2015). Effect of motivation on employee performance of commercial banks in Kenya: A case study of Kenya Commercial Bank in Migori County. International Journal of Human Resource Studies, 5(2), 87-103. https:// doi.org/10.5296/ijhrs.v5i2.7504
Oriarewo, G.O., Agbim, K.C., \& Owutuamor, Z.B. (2013). Job rewards as correlates of job satisfaction: Empirical evidence from the Nigerian banking sector. The International Journal of Engineering and Science, 2(8),62-69. Retrieved September 18, 2015, from http://www.theijes.com/papers/v2-i8/Part.1/K0281062068.pdf

Osa, R.G. (2014). Monetary incentives motivates employee's on organizational performance. Global Journal of Arts Humanities and Social Sciences, 2(7), 61-69. Retrieved October 06, 2015, from http://www.eajournals.org/wp-content/ uploads/Monetary-Incentives-Motivates-Employee---s-On-Organizationaluploads/Monetary

Osmani, M., Zaidi, A.R.M., \& Nilashi, M. (2014). Motivational factors, trust and knowledge sharing in organizations. International Journal of Innovation and Scientific Research, 12(2), 463-474. Retrieved October 17, 2015, from http:// webcache.googleusercontent.com/search?q=cache:k9e5Xbg11qMJ:www.issrjournals.org/links/papers.php\%3Fjournal\%3Dijisr\%26application $\% 3$ Dpdf $\% 26$ art journals.org/links/papers.php $\% 3 F j$ ournal\%3Dijisr\% $\%$ 26app
icle\%3DIJISR-14-218-03+\&cd=3\&hl=en\&ct=clnk\&gl=za

Ozütku, H. (2012). The influence of intrinsic and extrinsic rewards on employee results: An empirical analysis in Turkish manufacturing industry. Business and Economic Research Journal, 3(3), 29-48. https://doi.org/10.4236/jssm.2015.84047

Paliszkiewicz, J. (2011). Inter-organizational trust: Conceptualization and measurement. International Journal of Performance Measurement, 1, 15-28. Retrieved October 18, 2015, from https://pdfs.semanticscholar.org/22af/45ebc0 564fa32391edb8264418745363c0cd.pdf

Philips, C.J. (1997). Do you trust me? Executive Excellence, 14, 7-10.

Porter, L.W., \& Lawler, E.E. (1968). Managerial attitudes and performance. Homewood, IL: Dorsey Press.

Rafiq, M., Javed, M., Khan, M., \& Ahmed, M. (2012). Perceived competence, teacher autonomy -Support and parent attachment as predictors of students' academic achievement. European Journal of Business and Social Sciences, 1(12), 133-140. Retrieved September 14, 2015, from http://www.ejbss.com/Data/Sites/1/ marchissue2013vol12/ejbss-1217-13-perceivedcompetence.pdf

Ram, P., \& Prabhakar, G. (2011). Antecedent HRM practices for organizational commitment. International Journal of Business and Social Science, 2(2), 55-62. Retrieved September 14, 2015, from http://ijbssnet.com/journals/Vol._2_ No._2;_February_2011/6.pdf

Reinardy, S. (2010). Downsizing effects on personnel: The case of layoff survivors in U.S. newspapers. Journal of Media Business Studies, 7(4), 1-19. Retrieved July 02 2015, from https://kuscholarworks.ku.edu/bitstream/handle/1808/11244/ Reinardy-JMBS7-4.pdf? sequence=1

Rich, B.L. Lepine, J.A. \& Crawford, J.R. (2010). Job engagement: Antecedents and effects on job performance. Academy of Management Journal, 53(3), 617-635. https://doi.org/10.5465/AMJ.2010.51468988

Roberts, D.R., \& Davenport, T.O. (2002). Job engagement: Why it's important and how to improve it. Employment Relations Today, 29(3), 21-29. https://doi.org/10.1002/ ert.10048

Robyn, A., \& Du Preez, R. (2013). Intention to quit amongst Generation Y academics in higher education. South African Journal of Industrial Psychology, 39, 1-14. https:// doi.org/10.4102/sajip.v39i1.1106 Ross, K.N. (2005). Sample design for educational survey research. In K.N. Ross (Ed.),
Quantitative research methods in educational planning (pp. 1-83). Paris: IIEPUNESCO.

Rothmann, S., \& Hamukang'andu, L. (2013). Callings, work role fit, psychological meaningfulness and work engagement among teachers in Zambia. South African Journal of Education, 33(2), 1-16. https://doi.org/10.15700/saje.v33n2a699

Rothmann, S., \& Jordaan, G.M.E. (2006). Job demands, job resources and work engagement of academic staff in South African higher education institutions. South African Journal of Industrial Psychology, 32(4), 87-96. Retrieved September 12,2015 , from http://www.sajip.co.za/index.php/sajip/article/viewFile/247/244

Rothmann, S., \& Rothmann, S. (2010). Factors associated with employee engagement in South Africa. South African Journal of Industrial Psychology, 36(2), 1-12. https://doi.org/10.4102/sajip.v36i2.925

Ryan, R.M., \& Deci, E.L. (2000). Intrinsic and extrinsic motivations: Classic definitions and new directions. Contemporary Educational Psychology, 25, 54-67. https:// doi.org/10.1006/ceps.1999.1020

Saks, A.L. (2006). Antecedents and consequences of employee engagement. Journal of ManagerialPsychology,21(7),600-619.https://doi.org/10.1108/02683940610690169

Sanhari, M.S. (2014). Relationship between employee engagement and performance: A case study of health workers in Tanzania. International Journal of Engineering and Management Science, 5(3), 215-219. Retrieved July 06, 2015, from http:// connection.ebscohost.com/c/articles/97243510/relationship-betweenemployee-engagement-performance-case-study-health-workers-tanzania

Sajuyigbe, A.S., Olaoye, B.O., \& Adeyemi, M.A. (2013). Impact of reward on employees performance in a selected manufacturing companies in Ibadan, Oyo state, Nigeria. International Journal of Arts and Commerce, 2(2), 27-32. Retrieved October 06, 2015, from http://www.ijac.org.uk/images/frontlmages/gallery/Vol._2_No._2/4.pdf

Schaufeli, W.B., \& Bakker, A.B. (2003). UWES- Utrecht work engagement scale: Test manual. Department of Psychology, Utrecht University: Netherlands

Schaufeli, W.B., Salanova, M., Gonzalez-Roma, V., \& Bakker, A.B. (2002). The measurement of burnout and engagement: A confirmatory factor analytic approach. Journal of Happiness Studies, 3, 71-92. https://doi.org/10.1023/A 1015630930326

Scott, D., McMullen, T., \& Royal, M. (2012). Retention of key talent and the role of rewards. WorldatWork Journal, 21(4), 58-70. Retrieved October 06, 2015, from https://www.worldatwork.org/waw/adimLink?id=62016

Silverman, M. (2004). Non-financial recognition: The most effective of rewards. Brighton: Institute for Employment Studies. 
Six, F., Nooteboom, B., \& Hoogendoorn, A. (2010). Actions that build interpersonal trust: A relational signalling perspective. Review of Social Economy, 68(3), 285-315. https://doi.org/10.1080/00346760902756487

Sonnenberg, F.K. (1994). Ethics: Trust Me...Trust me not. Journal of Business Strategy, 15(1), 14-16. https://doi.org/10.1108/eb039609

Sousa-Lima, M., Michel, J.W., \& Caetano, A. (2013). Clarifying the importance of trust in organizations as a component of effective work relationships. Journal of Applied SocialPsychology,43(2),418-427.https://doi.org/10.1111/j.1559-1816.2013.01012.x

Spector, P.E. (1985). Measurement of human service staff satisfaction: Development of the Job Satisfaction Survey. American Journal of Community Psychology, 13, 693-713. https://doi.org/10.1007/BF00929796

Spretizer, G.M. (1995). Psychological empowerment in the workplace: Dimensions, measurement, and validation. Academy of Management Journal, 38(5), 14421465. https://doi.org/10.2307/256865

SPSS Inc. (2013). SPSS 22.0 for Windows. Armonk, NY: IBM Corp.

Stäbler, S.L., de Boer, H., \& Rosema, M. (2016). Basic need satisfaction with public sector internships and career aspiration of students: A self-determination theory approach. Unpublished thesis, University of Twente, Enschede, Netherlands.

Stumpf, S.A., Tymon, W.G., Jr., Favorito, N., \& Smith, R.R. (2013). Employees and change initiatives: Intrinsic rewards and feeling valued. Journal of Business Strategy, 34(2), 21-29. https://doi.org/10.1108/02756661311310422

Sundaray, B.K. (2011). Employee engagement: A driver of organizational effectiveness. European Journal of Business and Management, 3(8), 53-59. Retrieved Octobe 11, 2015, from http://pakacademicsearch.com/pdf-files/ech/517/53-59\%20 Vol\%203,\%20No\%208\%20(2011).pdf

Takawira, N., Coetzee, M., \& Schreuder, D. (2014). Job embeddedness, work engagement and turnover intention of staff in a higher education institution: An exploratory study. South African Journal of Human Resource Management, 12(1), 1-10. https://doi.org/10.4102/sajhrm.v12i1.524

Tamborini, R., Bowman, N.D., Eden, A., Grizzard, M., \& Organ, A. (2010). Defining media enjoyment as the satisfaction of intrinsic needs. Journal of Communication, 60(4), 758-777. https://doi.org/10.1111/j.1460-2466.2010.01513.x

Tan, H., \& Lim, A. (2009). Trust in co-workers and trust in organizations. The Journal of Psychology, 143(1), 45-66. https://doi.org/10.3200/JRLP

Terera, S.R., \& Ngirande, H. (2014). The impact of rewards on job satisfaction and employee retention. Mediterranean Journal of Social Sciences, 5(1), 481-487. https://doi.org/10.5901/mjss.2014.v5n1p481

Thirapatsakun, T., Kuntonbutr., \& Mechinda, P. (2014). The relationships among job demands, work engagement, and turnover intentions in the multiple groups of different levels of perceived organizational supports. Universal Journal of Management, 2(7), 272-285. https://doi.org/10.13189/ujm.2014.020703

Thomas, K.W. (2009). The four intrinsic rewards that drive employee engagement. Ivey Business Journal, 73(6), 1-12. Retrieved September 18, 2015, from http:// iveybusinessjournal.com/publication/the-four-intrinsic-rewards-that-driveemployee-engagement/

Tsede, O.A., \& Kutin, E. (2013). Total reward concept: A key motivational tool for corporate Ghana. Business and Economic Research, 3(2), 173-182. https://doi. org/10.5296/ber.v3i2.4291

Tzafrir, S. (2005). The relationship between trust, HRM, and firm performances. The International Journal of Human Resource Management, 16(9), 1600-1622. https://doi.org/10.1080/09585190500239135
Ugwu, F.O., Onyishi, I.E., \& Rodriguez-Sanchez, A.M. (2014). Linking organizational trust with employee engagement: The role of psychological empowerment. Personnel Review, 43(3), 377-400. https://doi.org/10.1108/PR-11-2012-0198

Van Aswegen, S., Botha, S., Kleynhans, R., Lotz, O., Markham, L., Meyer, W., perspectives. Cape Town, South Africa: Pearson Education Prentice Hall.

Van den Broeck, A., Vansteenkiste, M., De Witte, H., Soenens, B., \& Lens, W. (2010) Capturing autonomy, competence, and relatedness at work: Construction and initial validation of the Work-related Basic Need Satisfaction Scale. Journal of Occupational and Organizational Psychology, 83, 981-1002. https://doi.org/10. 1348/096317909X481382

Van der Berg, Y., \& Martins, N. (2013). The relationship between organisational trust and quality of work life.South African Journal of Human Resource Management 11(1). https://doi.org/10.4102/sajhrm.v11i1.392

Van Zyl, L.E., Deacon, E., \& Rothmann, S. (2009). Towards happiness: Experiences of work-role fit, meaningfulness and work engagement of industrial/organisational psychologists in South Africa. South African Journal of Industrial Psychology, 36(1). https://doi.org/10.4102/sajip.v36i1.890

Visser, A. (2012). Investigating the relationship between intrinsic and extrinsic reward, job satisfaction, organisational commitment and turnover intention. Unpublished master's thesis. North-West University, North-West, South Africa.

Waqas, S., \& Saleem, S. (2014). The effect of monetary and non-monetary rewards on Management, 6(31), 73-82. Retrieved July 18, 2015, from http://www.iiste.org/ Management, 6(31), 73-82. Retrieved July 18, 2015, from
Journals/index.php/EJBM/article/viewFile/16530/16937

Weatherly, R.L. (2002). Effects of external rewards on internal motivation and job satisfaction. Unpublished master's thesis, Texas Tech University, Texas, USA.

Wei, L.T., \& Yazdanifard, R. (2014). The impact of positive reinforcement on employees' performance in organizations. American Journal of Industrial and Business Management, 4, 9-12. https://doi.org/10.4236/ajibm.2014.41002

Williamson, J.C. (2011). Engagement and meaningfulness at work: The moderating roles of life satisfaction and gender. Unpublished master's dissertation, University of Johannesburg, Johannesburg, South Africa.

Wilson, R.K., \& Eckel, C.C. (2003). Trust and social exchange. In J.N. Druckman, D.P Green, H.J. Kuklinski, and A. Lupia (Eds.), The handbook of experimental political science, 243-257. Boston, Massachusetts: Cambridge University Press.

WorldatWork. (2006). Total rewards model: Strategies to attract, motivate and retain employees. Retrieved July 02, 2015, from http://WorldatWork.org/pub/total_ rewards_model.pdf

Yahya, K.K., Isa, S.N., \& Johari, J. (2012). Employees' perception on engagement and its relationship to HRM practices. Paper Presented at 3rd International Conference on Business and Economic Research, Bandung, Indonesia. Retrieved September 18, 2015, from http://repo.uum.edu.my/12246/

Zigarmi, D., Houson, D., Witt, D., \& Diehl, J. (2011). Employee work passion: Connecting the dots. Perspectives, 3, 1-10. Retrieved August 10, 2015, from http://www. kenblanchard.com/img/pub/blanchard_employee_passion_vol_3.pdf

Zhijian, H., \& Tianshu, N. (2013). Impact of total rewards on animation employees' engagement. Studies in Sociology of Science, 4(3), 58-64. https://doi.org/10. 3968/j.sss.1923018420130403.2501

Zikmund, W.G. (2003). Business research methods (7th ed.). Mason, Ohio: Thomson/ South-Western. 